\title{
Economic Analysis of the Corn Intercropped With Marandu Grass as a Function of Azospirillum brasilense Application
}

\author{
Viviane C. Modesto ${ }^{1}$, Marcelo Andreotti ${ }^{1}$, Omar J. Sabbag ${ }^{1}$, Deyvison de A. Soares ${ }^{1}$, Eduardo A. P. Pechoto ${ }^{1}$, \\ Isabô M. Pascoaloto ${ }^{2}$ \& Allan H. Nakao ${ }^{1}$ \\ ${ }^{1}$ College of Engineering, Sao Paulo State University, Ilha Solteira, SP, Brazil \\ ${ }^{2}$ College of Agronomic Sciences, São Paulo University, Botucatu, SP, Brazil \\ Correspondence: Viviane C. Modesto, Department of Plant Health, Rural Engineering, and Soils, College of \\ Engineering, Sao Paulo State University, Ilha Solteira, SP, Brazil. Tel: 55-18-3743-1000. E-mail: \\ vivimodesto12@gmail.com
}

Received: November 15, 2018

Accepted: December 15, 2018 Online Published: February 15, 2019

doi:10.5539/jas.v11n3p387

URL: https://doi.org/10.5539/jas.v11n3p387

The research was financed by São Paulo Research Foundation (FAPESP), grant 2014/02697-1.

\begin{abstract}
The Integrated Agricultural Production Systems (IAPS) under No-Tillage System (NTS), add values to grain production and to livestock activity over the year, besides providing reestablishment of degraded areas. The objective of this work was to evaluate the production costs and profitability of the irrigated corn crop, intercropped or not with Urochloa brizantha cv. Marandu, inoculated or not with Azospirillum brasilense, in the lowland Cerrado. The work was composed of two sequential experiments, conducted in Selvíria-MS, from 2015 to 2016. The experimental design of the two experiments was in randomized blocks with four replicates. The first experiment consisted of six treatments: (a) inoculate crop in single crop, (b) single corn crop without inoculation, (c) intercropping without inoculation, (d) intercropping with inoculation in both seeds, (e) intercropping with inoculation of corn seeds, and (f) intercropping with inoculation of grass seeds. In the corn off-season harvest, for the second experiment, the experimental units with grass were subdivided into three treatments: (a) leaf inoculated grass $(250 \mathrm{~mL}$ of inoculant), (b) grass broadcast fertilized with urea (200 $\mathrm{kg}$ of N $\mathrm{ha}^{-1}$ year $^{-1}$ ) in broadcast and (c) grass without fertilization or inoculation. The inputs were the most expensive components in corn production. In the intercropping treatments, where the grass was destined for silage, the profitability indexes were positive, enabling the system regardless of Azospirillum brasilense inoculation.
\end{abstract}

Keywords: growth promoting bacteria, integrated systems, no-tillage system, profitability indicators, Urochloa brizantha, Zea mays

\section{Introduction}

Considered the most important cereal in the world, especially because it is part of the raw material of the animal industry, corn crop continues to expand world-wide due to increasing investments in technology. Currently, the Brazilian production has a cropped area of over 5 million hectares (2017/18 harvest) and an estimated production over more 26 million hectares (CONAB, 2018).

Among other factors, the progress in the production of the crop is due to the remarkable increase in the occupation of the areas with No-tillage System. Out of 96 million hectares produced worldwide, over 30 million hectares are cultivated only in Brazil (FEBRAPDP, 2012).

Because of the need for a larger financial return to the producer, the use of intercropping in grain crops with forage species for the reestablishment of degraded areas and/or pasture recovery, since when properly managed in amended soils, grass crops amortizes the costs by forming, recovering and fertilizing the pastures.

The limited edaphoclimatic conditions, especially in the Cerrado region, means that there is a shortage of forage during the winter, which is characterized by low temperatures and rainfall, therefore, the farmers have to store food of better nutritional value in the form of silage, assuring good quality food for the animals during this period (Costa et al., 2015). 
In addition, when properly managed and associated with forages, sowing of the grain-producing crops anticipates the formation of the pastures, allowing the allocation of the animals in the area once grain is harvested, ensuring the synchronicity of the intercropping contributing to the increment in the income in the farm (Rodrigues et al., 2015).

Nevertheless, to guarantee the success of this activity, the technical and economic knowledge of all stages of crop management, such as behavior and competition factors among species, is essential to minimize costs and environmental risks. As a result, the available machinery and the residual effect of the fertilizers and correctives of the grain culture (Costa et al., 2015) are used, as is the case, mainly, of nitrogen.

Nitrogen is one of the nutrients that most burden the production costs in grain crops, which makes it necessary to invest in studies on reducing or saving their use. One of these lines of research is related to the benefits of biological nitrogen fixation promoted by the associative process of grasses with Azospirillum diazotrophic bacteria (Hungria et al., 2016).

Hence, the hypothesis of this work is that maize intercropped with marandu grass, combined with the use of diazotrophic growth promoting bacteria, amortize the production costs of the grain-producing crop, as well as the supply of grass for ensiling and maintenance of to the No-tillage System (NTS).

In this context, the objective of this work was to determine the technical coefficients matrix, to estimate and to evaluate the total operational cost and profitability indicators of the maize intercropped with marandu grass, submitted or not to the application of urea or Azospirillum brasilense in a Dystrophic Oxisol under sprinkler irrigation (central pivot), in low altitude Cerrado area from 2014 and 2016.

\section{Methods}

\subsection{Field Sites and Material Description}

This study was made up by two sequential experiments, repeated for two agricultural years (2014/15 and 2015/16), developed in a sprinkler irrigated area (central pivot) in Selvíria, State of Mato Grosso do Sul, Brazil $\left(20^{\circ} 20^{\prime} 05^{\prime \prime} \mathrm{S}\right.$ and $51^{\circ} 24^{\prime} 26^{\prime \prime} \mathrm{W}, 335 \mathrm{~m}$ above sea level). The soil of the experimental area was classified as typical clay Oxisol (Santos et al., 2018), and presented a history of 12 years under NTS, establishment phase, with annual and semiperennial crops, where soybean was the previous crop. The average, maximum and minimum temperature and rainfall of the experimental area are shown in Figure 1.

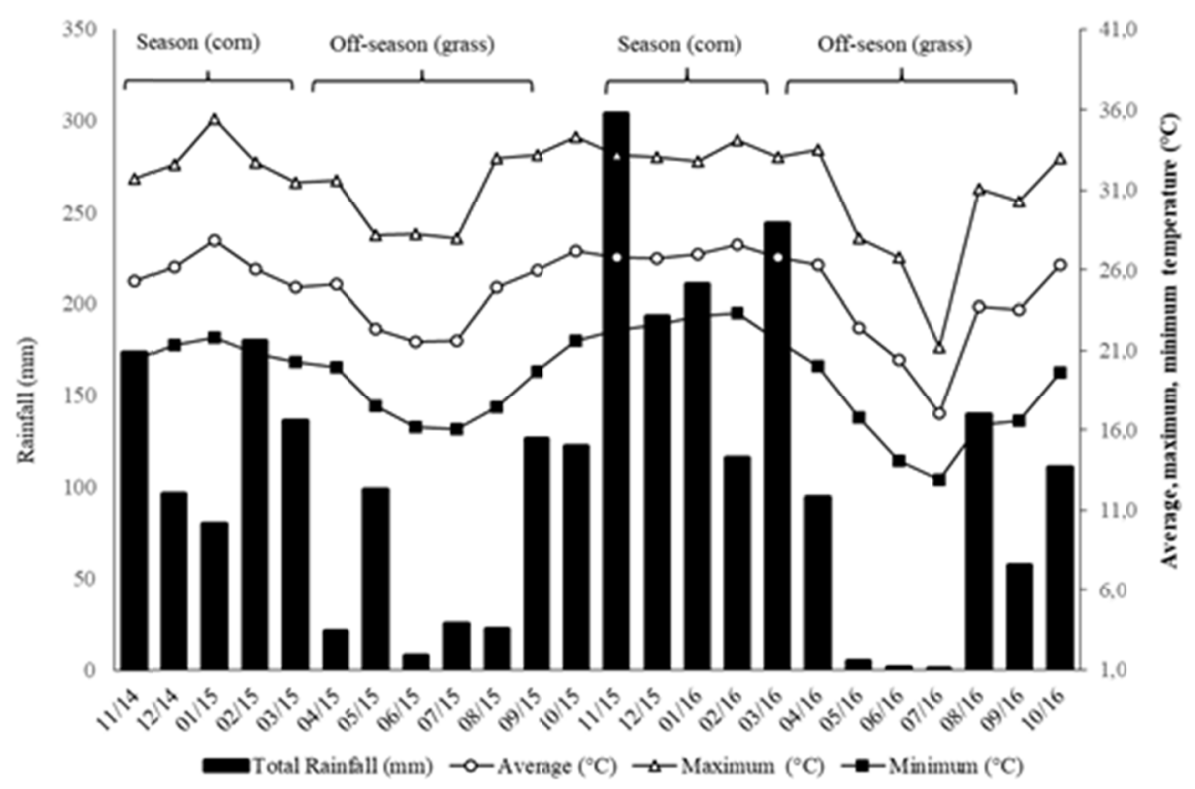

Figure 1. Climate data obtained from the UNESP Weather Station in Selvíria, Mato Grosso do Sul State, Brazil, from November 2014 to October 2013

\subsection{Experimental Design}

In both years, the area was irrigated by sprinkler (central pivot), considering the optimal water range for the crops under study. To establish the available water capacity (AWC), the following equation was used: 


$$
\mathrm{AWC}(\mathrm{mm})=[(\mathrm{FC}-\mathrm{PWP}) / 100] \times \mathrm{SD} \times \mathrm{PESR}
$$

Where, $\mathrm{FC}$ is field capacity (\%); PWP is the permanent wilting point (\%); SD is solid density $\left(\mathrm{kg} \mathrm{dm}^{-3}\right)$; and ERSD is the effective rooting system depth $(\mathrm{m})$. Data were obtained from soil water retention curve, where: FC $=20.25 \% ; \mathrm{PWM}=14.58 \% ; \mathrm{SD}=1.48$ and $0.93 \mathrm{~kg} \mathrm{dm}^{-3}, 2014 / 15$ and 2015/16 harvests, respectively; and $\mathrm{ERSD}=0.20 \mathrm{~m}$.

Therefore, the evaluated soil AWC was 16.78 and $11.54 \mathrm{~mm}$, for 2014/15 and 2015/16 harvests, respectively.

Water was supplied at a flow of $3.3 \mathrm{~mm} \mathrm{~h}^{-1}$. Irrigation was applied whenever maximum evapotranspiration of the crop $(\mathrm{ETm})$ reached 7.43 and $5.11 \mathrm{~mm}$ for the respective crops (less than $44.3 \%$ of the AWC). The ETm was estimated using the following equation:

$$
\operatorname{ETm}\left(\mathrm{mm} \mathrm{day}{ }^{-1}\right)=\mathrm{Kc} \times \mathrm{ETo}
$$

Where, Kc is the crop coefficient; and ETo is the reference evapotranspiration.

ETo was estimated using the following equation:

$$
\text { ETo }\left(\mathrm{mm} \mathrm{dia}{ }^{-1}\right)=\mathrm{Kp} \times \mathrm{CAE}
$$

Where, $\mathrm{Kp}$ is the coefficient of the Class A pan; and CAE is the class A evaporation pan (mm day $\left.{ }^{-1}\right)$. Measurement of water evaporation (mm) was obtained daily from a Class A pan. The Kp was calculated as proposed by Doorenbos and Pruitt (1977), based on the surrounding area, wind speed and air relative humidity.

Before the experiment set up, soil samples from the $0-0.10$ and $0.10-0.20 \mathrm{~m}$ depth layers were collected for chemical characterization (van RAIJ et al., 2001), where the following results were achieved: $18 \mathrm{mg} \mathrm{dm}^{-3} \mathrm{P}$ (resin); $20 \mathrm{~g} \mathrm{dm}^{-3}$ O.M.; $4.9 \mathrm{pH}\left(\mathrm{CaCl}_{2}\right) ; 3.5 ; 17.0 ; 15.0$ and 38.0 mmolc dm${ }^{-3} \mathrm{~K}, \mathrm{Ca}, \mathrm{Mg}$ and $\mathrm{H}+\mathrm{Al}$, respectively; 39.0 and $76.8 \mathrm{mmolc} \mathrm{dm}^{-3}$ BS and CEC; V $49 \%$ and $2 \mathrm{~m} \%$. As a result of soil analysis, 30 days prior to crop sowing, liming was applied (PRNT $85 \%, 32 \% \mathrm{CaO}$ and $18 \% \mathrm{MgO}$ ) in total area, with no incorporation aiming at rising base saturation by $70 \%$.

Before the experiment set up (October 2014), the counting of diazotrophic microorganisms in the soil was carried out to determine the bacterial population in number of cells per $\mathrm{mL}$, performed by the "Most Likely Number" (MLN) estimate using the MacCrady table in the semi-solid NFB medium (Azospirillum brasilense) according to methodology described by Döbereiner, Baldani, and Baldani (1995), where the value of $9.0 \times 10^{8}$ cells g$^{-1}$ was achieved.

The experimental design used in the first experiment was the randomized block, with four replications and six treatments, as follows: corn in single crop with inoculated seeds; corn in single crop without inoculated seeds; corn + marandu grass (intercropping) without inoculation; corn + marandu grass (intercropping) with inoculation in both seeds; maize + marandu grass (intercropping) with corn seeds inoculation and corn + marandu grass (intercropping) with inoculation of grass seeds. Each experimental unit consisted of $3.4 \mathrm{~m}$ in width and $20 \mathrm{~m}$ in length, totaling $68 \mathrm{~m}^{2}$. In the second experiment, the experimental units were allocated in the same place of the first year, the experimental design was a randomized block design, with four replications and three treatments, as follows: Marandu grass with no application of Azospirillum brasilense inoculum or nitrogen fertilization (control); Marandu grass with application of Azospirillum brasilense inoculant via leaves after the cut, at the dose of $250 \mathrm{~mL}$ in a volume of $200 \mathrm{~L} \mathrm{ha}^{-1}$ and Marandu grass with nitrogen fertilization $\left(50 \mathrm{~kg} \mathrm{ha}^{-1}\right.$ of N-urea, totaling $200 \mathrm{~kg}$ of N ha ${ }^{-1}$ year $^{-1}$ at the end of the four cuts, at intervals of 30 to 48 days each), in both harvests. Each unit originated from the subdivision of the experimental units of the first experiment that contained the grass from the intercropping with corn, which were constituted by $3.4 \mathrm{~m}$ in width and $6 \mathrm{~m}$ in length, making a total of $20.4 \mathrm{~m}^{2}$, with a floor area of $13.6 \mathrm{~m}^{2}$.

Prior to the installation of the experiment, for both harvests, the plants present in the experimental area were desiccated, aiming at the eradication of weeds and straw formation for continuity of the NTS, using the herbicide Glyphosate (1.44 $\mathrm{kg} \mathrm{ha}^{-1}$ of active ingredient (a.i.)) and subsequent mechanical management by using a horizontal plant residue crusher (Triton).

At sowing of the respective crops, 2014/15 and 2015/16, seeds of corn and marandu grass were inoculated or not with diazotrophic bacterium Azospirillum brasilense (strains Ab-V5 and Ab-V6) supplied by Total AZO liquid inoculant (Embrapa) at the dose of $100 \mathrm{~mL} / 25 \mathrm{~kg}$ of seeds. The inoculation occurred just before sowing and in the shade.

The corn crop (early hybrid DKB 390 YG and DKB 350 PRO, respectively) was mechanically sown by means of a sower-fertilizer with a knife-type plow mechanism for NTS at a depth of approximately $0.05 \mathrm{~m}$, spacing of $0.45 \mathrm{~m}$ and approximately 3.3 seed $\mathrm{m}^{-1}$, aiming to reach a final stand near 66000 plants ha $\mathrm{a}^{-1}$. 
In both harvests, forage (Urochloa brizantha cv. Marandu) seeding was performed sequentially to crop, using another seed-fertilizer, with a mismatched double-disk type furrow mechanism for NTS, where the seeds were put in the fertilizer compartment in the sower and deposited at a depth of $0.06 \mathrm{~m}$, at a spacing of $0.17 \mathrm{~m}$, using approximately $7 \mathrm{~kg} \mathrm{ha}^{-1}$ of viable pure seeds $(\mathrm{CV}=70 \%)$ for the marandu grass. As a result, grass seeds were below the corn seeds, following the recommendations of Kluthcouski et al. (2000) with the objective of delaying the emergence of the grass in relation to the grain-producing crop and decrease the likely competition between the species in the early development period of the crops.

According to the results of soil analysis in both cropping years, respectively, sowing mineral fertilization was carried out in grain-producing crop following the results of the soil analysis. So, $300 \mathrm{~kg} \mathrm{ha}^{-1}$ of the 08-28-16 formulated ( $24 \mathrm{~kg} \mathrm{ha}^{-1} \mathrm{~N}, 84 \mathrm{~kg} \mathrm{ha}^{-1} \mathrm{P}_{2} \mathrm{O}_{5}$ and $48 \mathrm{~kg} \mathrm{ha}^{-1} \mathrm{~K}_{2} \mathrm{O}$, respectively) were used.

As the corn crop reached the V6 phenological stage (six fully developed leaves), following the recommendations of van Raij and Cantarella (1997), the topdressing fertilization was carried out by applying manually, near the corn rows, the dose of $120 \mathrm{~kg} \mathrm{ha}^{-1}$ of $\mathrm{N}$ - as ammonium sulfate. Corn crop cycles for grain production were 140 and 120 days after emergence (DAE), in the $1^{\text {st }}$ and $2^{\text {nd }}$ years, respectively.

After crop harvesting in the respective harvests, grass productivity ( 4 cuts) was evaluated by using a $1.0 \times 1.0-\mathrm{m}$ metal square at a cut height of $0.30 \mathrm{~m}$ in each of the samples, where the cut material was taken to the air forced ventilation oven at $65^{\circ} \mathrm{C}$ for $72 \mathrm{~h}$, for the quantification of the total dry matter production extrapolated to $\mathrm{kg} \mathrm{ha}^{-1}$.

The costs per cultivation modality were estimated according to the methodology proposed by Matsunaga et al. (1976), which is the sum of the direct costing expenses: operations performed, inputs (liming, fertilizers, seeds and chemicals), labor, machinery and irrigation, denominated effective operational cost (EOC). For the calculation of indirect expenses, depreciation was considered by the linear method as a function of the ratio of the amount of fixed capital invested in the activity and the average useful life, financial charges, corresponding to $5.5 \%$ per year over $50 \%$ of EOC, as well as other operating expenses ( $5 \%$ of EOC), resulting in total operating cost (TCO).

For the calculation of the profitability indicators, the methodology of Martin et al. (1998) was used. So, gross income (RB), operating profit (OP) and profitability index (PI) were calculated. For elaboration of production costs of each treatment as well as profitability indicators, the prices paid for the products in 2015 and 2016 (Agrianual, 2015, 2016) were considered.

The income of each treatment was obtained considering the productivities (Table 2) and the price of $\mathrm{R} \$ 29.38$ $\mathrm{sack}^{-1}$ of grains for March/2015 and of R \$ 49.68 of sack $^{-1}$ of grains for March/2016, obtained by CEPEA.

Gross incomes of corn and marandu grass were estimated by the average productivity obtained in each treatment, multiplying it by the price paid to the producers and adding to the revenues of the two crops performed over the years.

\section{Results and Discussion}

The operational costs (operations and inputs) recorded in the experiment, in both harvests, to obtain the economic performance of the evaluated production systems were extrapolated to one hectare (Table 1). This TOC structure model was used in both harvests, including the establishment of the intercropping and management of the forage species during the off-season in the IAPS. It was verified that the most expensive corn production material in the two harvests were harvesting followed by irrigation of the area and sowing of the grass, totaling, on average, $8.6 \%, 4.03 \%$ and $2.62 \%$ of EOC described in Table 1 .

The input expenses, mainly for fertilizers $(53.80 \%$ of TOC) and corn seeds $(11.20$ TOC), were the most expensive components in the production systems analyzed in the first harvest (Table 1). Regarding corn seeds, it is justified because of its high technological level and also because in the first crop it was a simple hybrid (DKB 390 YG) with a high market value. It should be noted that the initial investment with liming was considered only for this harvest, following the recommendations of van Raij and Cantarella (1997), which raised the initial costs with the implementation of the production systems.

In the second year, even in the lack of liming, the inputs were responsible for the high cost of total production. These values result especially from the rise in the costs of triple hybrid corn seeds (13.98\% of TOC) and fertilizers (50.02\% of TOC) (Table 1$)$.

By evaluating intercropping of corn with Panicum and Urochloa forages under similar conditions of soil, climate and mechanical irrigation, Garcia et al. (2012), also observed that the highest expenditure on inputs was the purchase of hybrid corn seeds ( $45.88 \%$ of the TOC, on average), followed by the acquisition of fertilizers 
(38.52\% of the TOC, on average). These price oscillations over the years may influence the economic results of the productive systems, due to the high nutritional requirement of the grain-producing crop and forage intercropping in order to achieve high yields of corn and grass in the off season.

It should also be noted that the use of herbicides, normally used in single maize crops, was not necessary because in the intercropping of grass with the forage, the inhibition of the emergence or even the development of weeds depending on the cover species and the amount of straw that will be left on the ground may occur. Thus, this control of weeds occurs due to allelopathic activity and/or physical barrier formation of the straw, which prevents the survival of seeds germinated on the soil surface (Gomes Junior \& Christoffoleti, 2008), which will result in savings to the producer.

Operating costs represented only $21.47 \%$ of the TOC in the first harvest and $21.59 \%$ of the TOC in the second harvest, even in the absence of liming. Out of those, costs with the harvest were the most representative, 39.95\% in both harvests. Another operation that rise the costs of the system is mechanical irrigation, which represented $17.81 \%$ of the expenses in operations, however, this is an expense that can be reduced, according to the edaphoclimatic conditions of the evaluation periods.

Table 1. Estimate of the total operational cost of the operations and inputs used in the production of 1 ha of corn intercropped with marandu grass in the 2014/15 and 2015/16 harvests, in irrigated area

\begin{tabular}{|c|c|c|c|c|c|}
\hline Description & Specification & Coeff. & Unitary Value (R\$) & Total Value (R\$) $^{1}$ & Total Value (R\$) ${ }^{2}$ \\
\hline \multicolumn{6}{|l|}{ A-Operations } \\
\hline Desiccation & $\mathrm{HM}$ & 0.5 & 84.92 & 42.46 & 42.46 \\
\hline Limestone distribution & $\mathrm{HM}$ & 0.5 & 122.23 & 61.12 & 61.12 \\
\hline Hoeing & $\mathrm{HM}$ & 0.5 & 75.66 & 37.83 & 37.83 \\
\hline Corn fertilization & $\mathrm{HM}$ & 0.7 & 103.62 & 72.53 & 72.53 \\
\hline Grass fertilization & $\mathrm{HM}$ & 0.7 & 144.88 & 101.42 & 101.42 \\
\hline Leaf inoculation & $\mathrm{HH}$ & 1 & 9 & 9.00 & 9.00 \\
\hline Topdressing fertilization & $\mathrm{HH}$ & 1 & 9 & 9.00 & 9.00 \\
\hline Forage fertilization $(4 \times)$ & $\mathrm{HH}$ & 1 & 9 & 9.00 & 9.00 \\
\hline Harvest & $\mathrm{HM}$ & 1 & 330.95 & 330.95 & 330.95 \\
\hline Irrigation (central pivot) & $\mathrm{Mm}$ & 100 & 1.55 & 155.00 & 155.00 \\
\hline \multicolumn{4}{|l|}{ Subtotal A } & 828.31 & 828.31 \\
\hline \multicolumn{6}{|l|}{ B-Inputs } \\
\hline Dolomitic limestone & $\mathrm{tha}^{-1}$ & 2 & 145 & 290.00 & - \\
\hline N-P-K (08-28-16) fertilizer & $\mathrm{kg} \mathrm{ha}^{-1}$ & 300 & $1.6 / 1.5$ & 480.00 & 450.00 \\
\hline Ammonium sulphate & $\mathrm{kg} \mathrm{ha}^{-1}$ & 600 & $1.2 / 1.1$ & 720.00 & 660.00 \\
\hline Urea & $\mathrm{kg} \mathrm{ha}^{-1}$ & 450 & $1.6 / 1.5$ & 720.00 & 675.00 \\
\hline Glyphosate herbicide & $\mathrm{L} \mathrm{ha-}^{1}$ & 4 & $9.9 / 6.75$ & 39.60 & 27.00 \\
\hline A. brasilense inoculant & $\mathrm{L} \mathrm{ha}^{-1}$ & 1 & 10 & 10.00 & 10.00 \\
\hline \multicolumn{6}{|l|}{$\underline{\text { Seeds }}$} \\
\hline Corn (DKB 390) & sc ha ${ }^{-1}$ & 1.2 & $447 / 360$ & 536.40 & 432.00 \\
\hline U. brizantha $\mathrm{cv}$. Marandu & $\mathrm{kg} \mathrm{ha}^{-1}$ & 7 & $11.5 / 9$ & 80.50 & 63.00 \\
\hline \multicolumn{4}{|l|}{ Subtotal B } & 2586.50 & 2607.00 \\
\hline \multicolumn{4}{|c|}{ Effective operating costs (EOC) } & 3414.81 & 3435.00 \\
\hline \multicolumn{4}{|l|}{ Other expenses } & 170.74 & 171.77 \\
\hline \multicolumn{4}{|l|}{ Costing interests } & 93.91 & 94.47 \\
\hline \multicolumn{4}{|l|}{ Depreciation } & 155.69 & 155.69 \\
\hline \multicolumn{4}{|l|}{ Total operating costs (TOC) } & 3835.14 & $\mathbf{3 8 5 7 . 2 3}$ \\
\hline
\end{tabular}

Note. ${ }^{*} 5 \%$ of COE, Coeff. (Coefficient), ${ }^{1} 2014 / 15$ harvest; ${ }^{2}$ 2015/16 harvest.

Table 2 shows the two evaluated harvests and off-season harvests, the dry mass yield (DMY) of the marandu grass after intercropped with corn, the yield values in sacks ha ${ }^{-1}$ of corn, the COTs for each production system of grains and forage as well as the gross income (GI), operating income (OI) and profitability (PI). 
It was found that among the production systems, the largest TOC in both harvests were provided by the corn with inoculated seeds intercropped with Urochloa with no inoculation or the inverse, corn with no inoculation intercropped with inoculated Urochloa, with a cost of production that ranged from $\mathrm{R} \$ 3.857 .23$ to $\mathrm{R} \$ 3.835 .14$, respectively for 2014/15 and 2015/16 (Tables 3) and the lowest costs were for single corn systems, regardless of inoculation.

In addition, the work depicts high technological production systems, with fertilization and correction of soil fertility followed the crop requirements and mechanized irrigation, which justifies high TOC. It can be noted that the 12-year history of NTS probably resulted in greater accumulation of straw, carbon, organic phosphorus on the soil surface, as well as lower immobilization of $\mathrm{N}$, resulting in an enhancing in the soil physical and chemical attributes.

Grain yield was not affected by the intercropping, demonstrating that the competition among the intercropping species did not influence the productivity of these production systems. In several cases, researchers have reported that the presence of forage did not influence corn grain yield, neither (Pariz et al., 2009; Garcia et al., 2012; Costa et al., 2015; Kaneko et al., 2016). However, in some cases, the application of nicosulfuron herbicide at sub-doses was needed to reduce forage growth, as a way to guarantee the full development of corn, which did not occur in the present work, as already mentioned.

From the revenue and cost of production (Table 1), the economic profitability of corn production systems was analyzed by the revenue/cost ratio (Table 2). For the forage, the average price adopted in the region of this work was $R \$ 120.00$ per ton, in both years.

The 2014/2015 harvest was influenced by high temperatures in the most critical phase of the corn crop, which is the grain filling phase (Figure 1), where the temperature exceeded $38^{\circ} \mathrm{C}$, explaining the low productivity even in irrigated areas. With the lower development of the corn plant, the forage stood out, as it can be seen in Table 3 . In addition, Azospirillum species are known to produce growth promoting substances, such as auxins, gibberellins and cytokinins, promoting a more intense growth (Bashan \& De-Bashan, 2010) of the plants, resulting in a greater absorption and accumulation of nutrients.

It is likely that in the 2015/16 harvest, the corn crop had benefited from the residual effect of the previous year. The intercropping using a C4 forage species allows a greater coverage of the soil surface, therefore, Urochloa stands out because it is a species whose development of the aerial part allows the total coverage of the soil, protecting it from the erosive effect of the direct impact of the rain drops, minimizing the artificial sealing (Santos et al., 2014), besides contributing to the physical, chemical and microbiological attributes of the soil.

Gross income (GI) is directly related to productivity and average prices received by producers and was considered satisfactory for intercropping treatments. However, operating profit (OP) measures profitability in the short term, and presented positive results only for the intercropping treatments, in the first harvest, ranging from $\mathrm{R} \$ 113.58$ to R $\$ 1317.19$. In the second harvest, OP was positive in both systems, regardless of presence or absence of inoculation, ranging from $\mathrm{R} \$ 2669.43$ to $\mathrm{R} \$ 5698.67$.

The profitability index (PI), that is, the available rate of gross revenue that constitutes profitability, after payment of all operating costs (Martin et al., 1998), as well as OP, was positive in the intercropping systems, in the first year the value of $25.6 \%$ and in the second year $59.77 \%$. This average difference of $34.21 \%$ is due to the variables in the climatic conditions between the years (Figure 1) that resulted in higher corn production in the second harvest, thus raising the profitability index, as well as the higher commercialization price of the corn sacks, proving the importance of correct system, with the adoption of conservation practices of soil management and use of technologies and management of the system, are responsible for the economic results in the evaluated systems.

The highest PI for the treatment without inoculation may be related to the history of the area within 12 years in NTS which, according to Klutchcouski and Aidar (2003), presents a tendency over time to accumulate nutrients in the profile explored by the roots, making the response to macro and micronutrient fertilization less frequent.

The introduction of NTS in Integrated Systems such as the one used in this study (corn intercropped with Urochloa consortium) reduces the costs of implementing the system by 10 to $25 \%$ (Trecenti, Oliveira, \& Hass, 2008), which makes IAPS highly suitable for generating rural property sustainability with a financial return, especially to small farmers. 
Table 2. Dry matter yield (DMY), total operating cost (TOC), total productivity, gross income (GI), operating profit (OP), profitability index (PI), obtained from corn intercropped with marandu grass, in two harvests in irrigated area. 2014/15 and 2015/16 harvests

\begin{tabular}{|c|c|c|c|c|c|c|}
\hline \multirow{2}{*}{ Cropping Systems } & \multicolumn{6}{|c|}{ 2014/15 Harvest } \\
\hline & DMY & sc ha ${ }^{-1}$ & *TOC & GI & OP & PI \\
\hline & -- $\mathrm{kg} \mathrm{ha}^{-1}--$ & -- $60 \mathrm{~kg} \mathrm{--}$ & \multicolumn{3}{|c|}{ 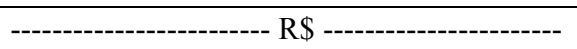 } & ----- \% ----- \\
\hline Corn & - & 117.82 & 3768.88 & 3461.45 & -307.43 & -8.88 \\
\hline Corn $+U$ & 5874 & 111.22 & 3836.76 & 5153.95 & 1317.19 & 25.56 \\
\hline Corn $+U(I)$ & 4241 & 109.18 & 3857.23 & 5094.21 & 1236.98 & 24.28 \\
\hline $\operatorname{Corn}(I)+U$ & 6795 & 110.20 & 3857.23 & 5124.08 & 1266.85 & 24.72 \\
\hline Corn (I) & - & 103.88 & 3789.35 & 3052.09 & -737.26 & -24.16 \\
\hline Corn $(I)+U(I)$ & 6381 & 104.98 & 3857.23 & 4970.81 & 113.58 & 22.40 \\
\hline \multirow{2}{*}{ Cropping system } & \multicolumn{6}{|c|}{ 2015/16 Harvest } \\
\hline & DMY & sc ha ${ }^{-1}$ & *TOC & GI & OP & PI \\
\hline & $--\mathrm{kg} \mathrm{ha}^{-1}--$ & -- $60 \mathrm{~kg} \mathrm{--}$ & ----------- & R\$ & ----------------- & ------ \% ----- \\
\hline Corn & - & 152.82 & 3727.93 & 7591.93 & 3864.00 & 50.90 \\
\hline Corn $+U$ & 2997 & 141.02 & 3814.67 & 8892.11 & 5077.44 & 57.10 \\
\hline Corn $+U(I)$ & 3335 & 131.68 & 3835.14 & 8428.43 & 4593.29 & 54.50 \\
\hline Corn (I) $+U$ & 3800 & 153.93 & 3835.14 & 9533.81 & 5698.67 & 59.77 \\
\hline Corn (I) & - & 129.18 & 3748.40 & 6417.83 & 2669.43 & 41.59 \\
\hline Corn $(I)+U(I)$ & 3408 & 126.75 & 3835.14 & 8183.34 & 4348.20 & 53.13 \\
\hline
\end{tabular}

Note. $U=$ Urochloa, I = Inoculated.

Given the benefits of the use of IAPS under NTS, it is necessary to pre-plan the activities on the property, from the choice of crops of interest suitable for the region and climate, based on climatic zoning, soil type, forage species purpose (straw, pasture or silage) and the market demand in that region. Thus, further studies are needed to evaluate the system as a whole, establishing the logistic aspects and limitations of each system, aiming for profitability and sustainability throughout the production chain.

\section{Conclusions}

Corn crop for grain production is profitable when intercropped with Marandu grass, regardless of whether or not it is inoculated with Azospirillum brasilense. In addition, it can be used to recover degraded areas, both for grain production and grass silage in the off-season harvest.

Despite the larger total operating cost, the intercropping systems provide a greater profitability index, especially in favorable climatic conditions to corn, due to higher grain yield, amortizing the production costs of the system and providing grass input to silage.

\section{References}

Agrianual. (2015). Anuário da Agricultura Brasileira (p. 472). São Paulo: Instituto FNP.

Agrianual. (2016). Anuário da Agricultura Brasileira (p. 456). São Paulo: Instituto FNP.

Bashan Y., \& Bashan L. E. (2010). How the plant growth-promoting bacterium Azospirillum promotes plant growth-A critical assessment Advances in Agronomy, 108(1), 77-136. https://doi.org/10.1016/S0065-2113 (10)08002-8

Cantarella, H., van Raij, B., \& Camargo C. E. O. (1997). Cereais. In B. van Raij, H. Cantarella, J. A. Quaggio, \& A. M. C. Furlani (Eds.), Boletim técnico 100: Recomendação de adubação e calagem para o Estado de São Paulo (2nd ed., pp. 43-71). Campinas: Instituto Agronômico-IAC.

CEPEA (Centro de Estudos Avançados em Economia Aplicada). (2018). PIB Agro CEPEA-USP/CNA. Retrieved from https://www.cepea.esalq.usp.br/br/indicador/milho.aspx

CONAB (Companhia Nacional de Abastecimento). (2018). Acompanhamento de safra brasileiro-grãos: Décimo primeiro levantamento, agosto 2018-safra 2017/2018. Brasília: Companhia Nacional de Abastecimento. Retrieved from https://www.conab.gov.br/component/k2/item/download/21709_4d6f8550138ed03890d0bb a9f9db1675 
Costa, N. R., Andreotti, M., Bergamaschine, A. F., Lopes K. S. M., \& Lima, A. E. S. (2015). Custo de produção de silagens em sistemas de integração lavoura-pecuária sob plantio direto. Revista Ceres, 62, $009-019$. https://doi.org/10.1590/0034-737X201562010002

Döbereiner, J., Baldani, V. L. D., \& Baldani, J. I. (1995). Como isolar e identificar bactérias diazotróficas de plantas não leguminosas (p. 80). Brasília: EMBRAPA-SPI.

Doorenbos, J., \& Pruitt, W. O. (1977). Guidelines for predicting crop water requirements (p. 179). Rome: FAO.

FEBRAPDP (Federação Brasileira de Plantio Direto na Palha). (2012). Foz do Iguaçu-PR. Retrieved from https://febrapdp.org.br/download/PD_Brasil_2013.jpg

Garcia, C. M. P., Andreotti, M., Tarsitano, M. A. A., Teixeira Filho, M. C. M., Lima, A. E. S., \& Buzetti, S. (2012). Análise econômica da produtividade de grãos de milho consorciado com forrageiras dos gêneros Urochloa e Megathyrsus em sistema plantio direto. Revista Ceres, 59, 157-163. https://doi.org/10.1590/ S0034-737X2012000200002

Gomes Junior, F. G., \& Christoffoleti, P. J. (2008). Biologia e manejo de plantas daninhas em áreas de plantio direto. Planta Daninha, 26(34), 789-798. https://doi.org/10.1590/S0100-83582008000400010

Hungria, M., Nogueira, M. A., \& Araujo, R. S. (2016) Inoculation of Brachiaria spp. with the plant growth-promoting bacterium Azospirillum brasilense: An environment-friendly component in the reclamation of degraded pastures in the tropics. Agriculture, Ecosystems \& Environment, 221(1), $125-131$. https://doi.org/10.1016/j.agee.2016.01.024

Kaneko, F. H., Sabundjian, M. T., Arf, O., Leal, A. J. F., L. F., Carneiro, L. F., \& Paulino, H. B. (2016). Análise econômica do milho em função da inoculação com Azospirillum, fontes e doses de N em cobertura. Revista Brasileira de Milho e Sorgo, 15(2), 202-216. https://doi.org/10.18512/1980-6477/rbms.v15n2p202-216

Kluthcouski, J., \& Aidar, H. (2003) Implantação, condução e resultados obtidos com o sistema Santa Fé. In J. Kluthcouski, L. F. Stone, \& H. Aidar (Eds.), Integração Lavoura Pecuária (pp. 407-442). Santo Antônio de Goiás: Embrapa Arroz e Feijão.

Kluthcouski, J., Cobucci, T., Aidar, H., Yokoyama, L. P., Oliveira, I. P., Costa, J. L. S., Vilela, L., Barcellos, A. O., \& Magnabosco, C. U. (2000). Sistema Santa Fé: Tecnolgia Embrapa: Integração lavoura-pecuária pelo consórcio de culturas anuais com forrageiras, em áreas de lavoura, nos sistemas direto e convencional (Circular Técnica, 38). Santo Antônio de Goiás: Embrapa Arroz e Feijão.

Martin, N. B., Serra, R., Oliveira, M. D. M., Angelo, J. A., \& Okawa, H. (1998). Sistema integrado de custos agropecuários-CUSTAGRI. Informações Econômicas, 28, 7-28.

Matsunaga, M., Bemelmans, P. F., \& Toledo, P. (1976). Metodologia de custo de produção utilizada pelo IEA. Agricultura em São Paulo, 23, 123-139.

Pariz, C. M., Andreotti, M., Tarsitano, M. A. A., Bergamaschine, A. F., Buzetti, S., \& Chioderoli, C. A. (2009) Desempenhos técnicos e econômicos da consorciação de milho com forrageiras dos gêneros Panicum e Brachiaria em sistema de integração lavoura-pecuária. Pesquisa Agropecuária Tropical, 39(4), 360-370.

Rodrigues, M., Rabêlo, F. H. S., Bernardi, D. B., \& Lange, A. (2015) Análise econômica de consórcios de Brachiaria brizantha com culturas graníferas anuais voltados para a recuperação de pastagens na Amazônia Revista Brasileira de Ciências Agrárias, 10, 82-90. https://doi.org/10.5039/agraria.v10i1a5084

Santos, H. G., Jacomine, P. K. T., Anjos, L. H. C. dos, Oliveira, V. A. de Lumbreras, J. F., Coelho, M. R., ... Oliveira, J. B. de. (2018). Sistema brasileiro de classificação de solos (5th ed.). Brasília, DF: Embrapa.

Silva, F. A., Lopes, F. C. F., Rocha, P. R., Cunha, R. L., Dallabona Dombroski, J. L. X., Holanda, J. L. C., ... Mayky, F. P. L. (2015). Milho para ensilagem cultivado nos sistemas de plantio direto e convencional sob efeito de veranico. Semina: Ciências Agrárias, 36(1), 327-340. https://doi.org/10.5433/1679-0359.2015 v36n1p327

Trecenti, R., Oliveira, M. C., \& Hass, G. (2008). Integração lavoura-pecuária-silvicultura (p. 54). Brasília: MAPA/SDC.

Van Raij, B., Andrade, J. C., Cantarella, H., \& Quaggio, J. A. (2001) Análise química para avaliação da fertilidade de solos tropicais (p. 284). Campinas: Instituto Agronômico. 


\section{Copyrights}

Copyright for this article is retained by the author(s), with first publication rights granted to the journal.

This is an open-access article distributed under the terms and conditions of the Creative Commons Attribution license (http://creativecommons.org/licenses/by/4.0/). 